Clinical Tests of Respiratory Function 


\title{
CLINICAL TESTS OF \\ RESPIRATORY FUNCTION
}

\author{
G. J. Gibson, B.Sc., M.D., F.R.C.P.
}

Consultant Physician, Freeman Hospital, Newcastle upon Tyne, UK

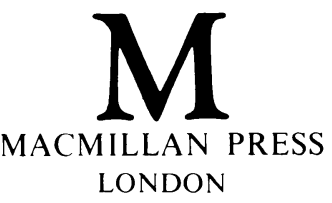


() G. J. Gibson 1984

Softcover reprint of the hardcover 1st edition 1984 978-0-333-32568-1

All rights reserved. No part of this publication may be reproduced or transmitted, in any form or by any means, without permission.

First published 1984 by

The Scientific and Medical Division

THE MACMILLAN PRESS LTD

London and Basingstoke

Companies and representatives throughout the world

ISBN 978-1-349-81335-3 ISBN 978-1-349-81333-9 (eBook)

DOI 10.1007/978-1-349-81333-9

Typeset in Great Britain by

RDL Artset Ltd, Sutton, Surrey 


\section{Contents}

Preface $\quad$ xi

Acknowledgements $\quad$ xiii

1 EQUIPMENT

1.1 Volume measurement 1

1.2 Pressure measurements 3

1.3 Measurement of flow 4

$\begin{array}{ll}1.4 & \text { Whole body plethysmographs }\end{array}$

$\begin{array}{lll}1.5 & \text { Gas analysers } & 7\end{array}$

1.6 Respiratory mass spectrometer 9

$\begin{array}{lll}1.7 & \text { Radioisotope measurement } & 11\end{array}$

$\begin{array}{lll}1.8 & \text { Blood gas analysis } & 11\end{array}$

$\begin{array}{llr}1.9 & \text { Recorders } & 12\end{array}$

2 TESTS OF MECHANICAL FUNCTION

$\begin{array}{lll}2.1 & \text { Measurements of total ventilation } & 14\end{array}$

2.2 Mechanics of inspiration and expiration $\quad 15$

$\begin{array}{ll}2.3 \text { Lung distensibility } & 25\end{array}$

$\begin{array}{lll}2.3 .1 & \text { Pressure-volume curve of the lungs } & 25\end{array}$

2.3.2 Measurements of lung volume and its subdivisions $\quad 30$

$\begin{array}{lll}2.4 & \text { Chest wall function } & 32\end{array}$

$\begin{array}{ll}2.5 & \text { Airway function } \\ & 35\end{array}$

$\begin{array}{ll}\text { 2.5.1 Determinants of airways resistance } & 35\end{array}$

$\begin{array}{ll}2.5 .2 & \text { Determinants of maximum flow } \\ 2.5 .3 & 38\end{array}$

2.5.3 Interrelations of tests of airway function $\quad 46$

2.6 Obstructive and restrictive defects 48

3 TESTS OF GAS EXCHANGE FUNCTION

3.1 Ventilation $\quad 54$

$\begin{array}{lll}3.2 & \text { Diffusion } & 61\end{array}$

$\begin{array}{lll}3.3 & \text { Perfusion } & 68\end{array}$

$\begin{array}{lll}3.4 & \text { Ventilation-perfusion relationships } & 71\end{array}$

$\begin{array}{lll}3.5 & \text { Regional lung function } & 84\end{array}$

3.6 Oxygen carriage by the blood 85

$\begin{array}{ll}3.7 & \text { Carbon dioxide carriage by the blood } \\ \end{array}$ 
4 TESTS OF VENTILATORY CONTROL

$\begin{array}{lll}4.1 & \text { Neural control mechanisms } & 100\end{array}$

$\begin{array}{ll}4.2 \text { Chemical control of breathing } & 101\end{array}$

\section{EXERCISE TESTS}

$\begin{array}{lll}5.1 & \text { Physiological responses to exercise } & 110\end{array}$

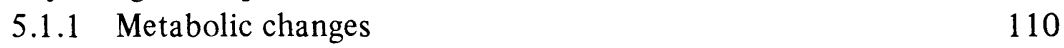

5.1.2 Ventilatory adaptations and gas exchange 111

$\begin{array}{lll}5.1 .3 & \text { Circulatory responses } & 114\end{array}$

5.1.4 Normal limiting factors and fitness $\quad 116$

$\begin{array}{ll}5.2 \text { Types of exercise test } & 116\end{array}$

5.2.1 Simple tests 117

$\begin{array}{ll}\text { 5.2.2 Progressive exercise testing } & 117\end{array}$

$\begin{array}{ll}\text { 5.2.3 Steady-state tests } & 118\end{array}$

$\begin{array}{ll}5.3 \text { Heart or lungs? } & 120\end{array}$

6 PHYSIOLOGICAL VARIATION

$\begin{array}{ll}\text { 6.1 Size, sex and ethnic differences } & 122\end{array}$

$\begin{array}{ll}6.2 \text { Growth and ageing } & 124\end{array}$

\begin{tabular}{lll}
6.3 Posture & 127 \\
\hline & 128
\end{tabular}

$\begin{array}{lll}6.4 & \text { Diurnal variation and sleep } & 128\end{array}$

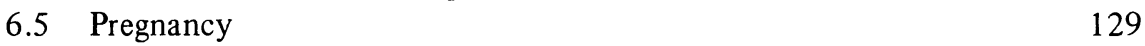

$\begin{array}{lll}6.6 & \text { Environment and srnoking } & 129\end{array}$

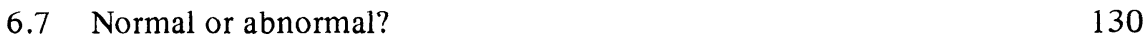

\section{AIRWAY DISEASES}

$\begin{array}{lll}7.1 & \text { Chronic airflow obstruction } & 134\end{array}$

7.1.1 Statics: PV relationships and lung volumes 134

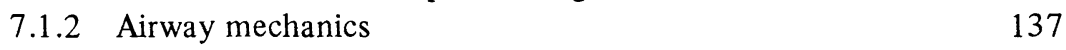

7.1.3 Pulmonary gas exchange and oxygen transport 141

$\begin{array}{lll}7.1 .4 & \text { Tests of diffusion } & 144\end{array}$

7.1.5 Ventilatory control and $\mathrm{CO}_{2}$ retention 144

$\begin{array}{lll}7.1 .6 & \text { Acute respiratory failure } & 146\end{array}$

$\begin{array}{lll}7.1 .7 & \text { Exercise } & 148\end{array}$

7.1.8 'Bronchial' and 'emphysematous' types of chronic airflow $\begin{array}{ll}\text { obstruction } & 150\end{array}$

$\begin{array}{ll}\text { 7.1.9 Emphysematous bullae } & 151\end{array}$

7.1.10 Evolution of chronic airflow obstruction and sensitive tests 152

$\begin{array}{ll}7.1 .11 \text { Bronchiectasis } & 154\end{array}$

$\begin{array}{ll}7.1 .12 \text { Cystic fibrosis } & 155\end{array}$

$\begin{array}{ll}7.1 .13 \text { Macleod's syndrome } & 157\end{array}$

$\begin{array}{lll}7.2 & \text { Asthma } & 157\end{array}$

$\begin{array}{lll}7.2 .1 & \text { Statics } & 157\end{array}$ 
7.2.3 Tests of gas exchange 164

7.2.4 Ventilatory control 166

$\begin{array}{lll}7.2 .5 & \text { Exercise } & 169\end{array}$

7.2.6 Inhalation challenge tests and bronchial hyperreactivity 171

$\begin{array}{ll}\text { 7.2.7 Allergic bronchopulmonary aspergillosis } & 175\end{array}$

$\begin{array}{lll}7.2 .8 & \text { Byssinosis } & 175\end{array}$

$\begin{array}{lll}7.3 & \text { Upper respiratory tract infections } & 176\end{array}$

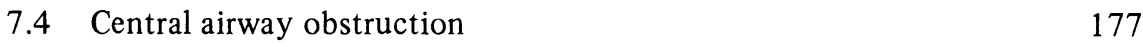

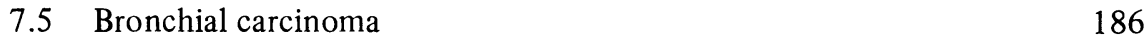

\section{ALVEOLAR DISEASES}

8.1 Surgical removal of lung tissue 199

8.2 Cryptogenic fibrosing alveolitis 200

8.2.1 Static mechanical function 200

8.2.2 Airway function 202

8.2.3 Gas exchange function 208

8.2.4 Exercise performance 209

8.2.5 Relation of function to pathological, radiographic and clinical features $\quad 209$

8.3 Extrinsic allergic alveolitis 210

8.4 Sarcoidosis 211

8.5 Miscellaneous conditions 212

8.5.1 Eosinophil granuloma $\quad 212$

$\begin{array}{ll}\text { 8.5.2 Chronic eosinophilic pneumonia } & 212\end{array}$

8.5.3 Alveolar proteinosis 213

8.6 Pneumoconioses 213

8.6.1 Asbestosis 213

8.6.2 Coal workers' pneumoconiosis 214

$\begin{array}{lll}\text { 8.6.3 Silicosis } & 215\end{array}$

8.7 Pneumonia 215

$\begin{array}{lll}8.8 \text { 'Shock lung' } & 216\end{array}$

9 DISEASES OF PLEURA AND CHEST WALL

9.1 Pneumothorax

9.2 Pleural effusion 225

$\begin{array}{lll}9.3 & \text { Pleural thickening } & 227\end{array}$

9.4 Ankylosing spondylitis 228

$\begin{array}{lll}9.5 & \text { Scoliosis } & 229\end{array}$

9.6 Thoracoplasty 231

9.7 Pectus excavatum 231 
PULMONARY VASCULAR DISEASE

10.1 Pulmonary thromboembolism

10.2 Primary pulmonary hypertension

$\begin{array}{ll}10.3 \text { Non-thrombotic pulmonary embolism } & 237\end{array}$

$\begin{array}{ll}10.4 \text { Pulmonary veno-occlusive disease } & 238\end{array}$

$\begin{array}{ll}10.5 \text { Pulmonary arteriovenous malformations } & 238\end{array}$

\section{CARDIAC DISEASE}

$\begin{array}{lll}11.1 \text { Cardiac failure } & 240\end{array}$

$\begin{array}{ll}\text { 11.2 Mitral valve disease } & 242\end{array}$

$\begin{array}{ll}11.3 \text { Aortic valve disease } & 245\end{array}$

$\begin{array}{ll}11.4 \text { Left-to-right shunts } & 246\end{array}$

$\begin{array}{lll}11.5 & \text { Right-to-left shunts } & 247\end{array}$

\section{BLOOD DISORDERS}

$\begin{array}{lll}12.1 \text { Anaemia } & 252\end{array}$

$\begin{array}{ll}12.2 \text { Polycythaemia } & 256\end{array}$

$\begin{array}{ll}12.3 \text { Haemoglobinopathies } & 257\end{array}$

$\begin{array}{ll}\text { 12.3.1 Sickle-cell anaemia } & 257\end{array}$

$\begin{array}{ll}\text { 12.3.2 Thalassaemia } & 257\end{array}$

12.3.3 Haemoglobins with altered oxygen affinity 258

\section{NEUROMUSCULAR DISEASES}

13.1 Abnormalities of respiratory control 261

$\begin{array}{ll}\text { 13.1.1 Patterns of breathing with CNS lesions } & 261\end{array}$

13.1.2 Central alveolar hypoventilation $\quad 264$

13.1.3 Sleep apnoea syndromes $\quad 266$

$\begin{array}{ll}13.2 \text { Consequences of respiratory muscle weakness } & 269\end{array}$

$\begin{array}{ll}\text { 13.2.1 Global weakness } & 269\end{array}$

$\begin{array}{ll}\text { 13.2.2 Bilateral diaphragm paralysis } & 272\end{array}$

$\begin{array}{ll}\text { 13.2.3 Unilateral diaphragm paralysis } & 272\end{array}$

$\begin{array}{ll}\text { 13.3 Specific conditions of the central nervous system } & 273\end{array}$

$\begin{array}{ll}\text { 13.3.1 Hemiplegia } & 273\end{array}$

$\begin{array}{ll}\text { 13.3.2 Cerebellar ataxia } & 273\end{array}$

$\begin{array}{ll}\text { 13.3.3 Parkinson's disease } & 273\end{array}$

$\begin{array}{ll}\text { 13.3.4 Paraplegia and quadriplegia } & 273\end{array}$

$\begin{array}{ll}\text { 13.3.5 Poliomyelitis } & 274\end{array}$

13.3.6 Motor neurone disease $\quad 275$

13.4 Specific conditions of peripheral nerve and muscle 276

$\begin{array}{ll}\text { 13.4.1 Acute polyneuritis } & 276\end{array}$

$\begin{array}{ll}\text { 13.4.2 Myasthenia gravis } & 276\end{array}$

$\begin{array}{ll}\text { 13.4.3 Muscular dystrophies } & 276\end{array}$

13.4.4 Myotonic dystrophy (dystrophia myotonica) 276

$\begin{array}{ll}\text { 13.4.5 Other myopathies } & 277\end{array}$ 
14 RENAL DISEASES

$\begin{array}{ll}\text { 14.1 Chronic renal failure } & 283\end{array}$

$\begin{array}{ll}14.2 \text { Effects of haemodialysis } & 284\end{array}$

$\begin{array}{ll}14.3 \text { Goodpasture's syndrome } & 285\end{array}$

15 HEPATIC AND BOWEL DISEASE

$\begin{array}{lll}15.1 \text { Hepatic disease } & 287\end{array}$

$\begin{array}{ll}15.2 \text { Bowel disease } & 289\end{array}$

16 METABOLIC AND ENDOCRINE DISORDERS

16.1 Obesity 291

16.2 Malnutrition 292

$\begin{array}{ll}16.3 \text { Thyroid disease } & 292\end{array}$

16.3.1 Hyperthyroidism 292

16.3.2 Hypothyroidism 294

16.4 Pituitary disease 295

16.4.1 Acromegaly 295

16.4.2 Hypopituitarism 296

17 SYSTEMIC VASCULITIS AND COLLAGEN DISEASES

17.1 Systemic vasculitides 299

$\begin{array}{ll}17.2 \text { Rheumatoid arthritis } & 300\end{array}$

17.3 Systemic sclerosis (scleroderma) 301

17.4 Systemic lupus erythematosus 302

17.5 Dermatomyositis and polymyositis 304

17.6 Mixed connective tissue disease 304

17.7 Sjögren's syndrome 304

$\begin{array}{ll}17.8 \text { Relapsing polychondritis } & 305\end{array}$

18 CLINICAL APPLICATION OF RESPIRATORY FUNCTION TESTS

18.1 The patient with suspected asthma 309

18.2 The patient with 'unexplained' dyspnoea 309

18.3 Suspected upper airway obstruction $\quad 310$

18.4 Responses to treatment 311

18.5 Preoperative assessment 311

$\begin{array}{ll}\text { Glossary of terms, abbreviations and units } & 313\end{array}$

$\begin{array}{ll}\text { Index } & 321\end{array}$ 


\section{Preface}

Tests of respiratory function have been available for clinical use for about 30 years but they are still not fully integrated in the mainstream of clinical medicine. I think they are often ill understood and therefore frequently misused, or, more importantly, not used when they should be. The main aim of this book is to narrow the divide between respiratory physiology and the lung function laboratory on the one hand, and the bedside or outpatient clinic on the other. To a large extent, the failure to apply the tests appropriately stems from the misguided feeling that complicated laboratory-based measurements are needed, when, in fact, simple tests used in the ward or clinic are often of much greater value. To many the jargon and hieroglyphics of respiratory physiology are undoubtedly inhibiting and, it must be admitted, respiratory physiologists have themselves been to blame for perpetuating the mystique of their subject and often for failing to promote a pragmatic approach which can be routinely applied to clinical situations. The more tests used and the more indices recorded, the more superficially impressive (and perhaps the more lucrative) is the report on an individual patient; the disadvantages of this approach are that it dilutes the clinical relevance of the information and may assault the comprehension of its recipient.

I hope this book will be of value to respiratory physicians in practice and in training, and particularly to those involved in the interpretation of the commonly performed tests of respiratory function. The tests described are conventional measurements of function of the 'whole organ'; tests of respiratory function in the broadest sense might also include biochemical and subcellular techniques applied to bronchial secretions, lung tissue or fluid lavaged from the lung, as well as studies of pulmonary metabolism and of the way drugs are handled by the lung. All these are expanding fields but so far none has generated a widely applicable clinical test.

This book is not primarily a laboratory manual with a detailed technical account of the tests, nor does it give comprehensive normal or reference values as these are fully covered elsewhere, notably by Cotes. The choice of tests included is a personal one - I did not set out to cover every conceivable test, but I have concentrated on those that I find to be of value in assessing the severity of a functional disturbance, in elucidating its mechanism, in differential diagnosis and in following responses to treatment. I have included a few tests that are of doubtful clinical applicability (e.g. the $D_{\mathrm{m}}$ and $V_{\mathrm{c}}$ components of the CO Diffusing Capacity), or are too demanding of technology for widespread use (e.g. the multiple inert gas technique of Wagner and West), where these aid the understanding or interpretation of simpler tests. I must also admit that occasionally the criterion for inclusion of an unusual feature or piece of information has been simply that I find it interesting. In many situations the exact pathogenesis of abnormali- 
ties of respiratory function tests is ill understood, but where specific mechanisms are established or likely, I have tried to explain these, with the philosophy that sensible application of the tests is more likely to result from understanding or from a questioning attitude than from ignorance or unwarranted assumptions.

After a brief description of apparatus, the book falls into three main sections. Chapters 2 to 6 aim to describe the theoretical and practical aspects of the commonly applied tests of mechanical and gas exchange function, of respiratory control and exercise, together with the causes of their variations in normal subjects. Chapters 7 to 10 deal with diseases that would normally be within the purview of the respiratory physician. In chapters 11 to 17 , diseases primarily of other bodily systems are discussed (sometimes with rather arbitrary groupings); I hope that this less conventional section will give a timely review of the considerable recent literature on respiratory function in non-respiratory disease, which has emphasised the high frequency with which unexpected abnormalities come to light. Finally, in Chapter $18 \mathrm{I}$ attempt to give some guidelines on the everyday application of the tests. I have not given specific examples of results of conventional tests in the commoner clinical conditions: I hope these patterns of abnormality will be self-evident and in any case they will be familiar to most readers. I have, however, included some examples of less commonly applied tests, such as maximum flow-volume curves and radioisotope scans. The density of referencing is variable: where long-established findings or generally accepted views are quoted I have generally only listed one or two important works; the referencing is more comprehensive when the results or opinions are recent, speculative, controversial or unexpected. The vexed problem of units also deserves a mention: my own view is that the introduction of SI units for blood gas measurements has made a mildly difficult subject more complicated, and since the system has (predictably) been only half-heartedly adopted by only half the individuals in the field, anyone sufficiently interested to consult the literature needs to be conversant with both SI and traditional units. For this reason many figures show a dual scale, but in the text my prejudice in favour of $\mathrm{mmHg}$ or $\mathrm{cmH}_{2} \mathrm{O}$ surfaces from time to time. 


\section{Acknowledgements}

I owe a considerable debt to several individuals who stimulated and nurtured my interest in the field of clinical respiratory physiology. In particular I would mention Moran Campbell, Richard Edwards, Charles Fletcher, Michael Hughes, Norman Jones and especially Neil Pride to whom I am very thankful for help and guidance over many years. In the preparation of the manuscript I am very grateful to Mrs Beverley Wears for her typing skill, to Mrs Barbara Brown who was responsible for most of the illustrations and to Drs Paul Corris and J. J. Gilmartin for helpful comments on the text. I would also thank The Macmillan Press Ltd and my wife Mary who each in their different way showed considerable forbearance during the book's gestation period.

I am very grateful to $\mathrm{Mr}$ Terry Hawkins for allowing me to use the radioisotope scans illustrated in figures 7.6, 7.10, 7.30, 10.2, 11.3 and 11.5. Figures 7.13 and 7.15 are reproduced with permission from Gibson, G. J., Pathophysiology and clinical correlates of asthma, in: Clark, T. J. H. (ed.) Steroids in Asthma, ADIS, Auckland, 1983. Other authors whose figures are reproduced or redrawn are individually acknowledged in the legends. 